The Wabash rule does place non-cumulative stocliholders largely at the mercy of a board of directors. If common stockholders will forego immediate dividends, directors can channel a disproportionate share of the corporation's profits away from non-cumulative preferred. Annual earnings may be retained for several years. After non-cumulative preferred has received merely the current year's dividend, common stock may be liberally rewarded with the retained earnings themselves ${ }^{23}$ or, more subtly, with profits which the preferred's retained dividends have financed. To stir a court to remedial action, non-cumulative stockholders must at least prove that earnings vere retained in conflict with "wise administration of a going concern." 27 But since most boards can readily discover some contingent liability or expansion plan justifying retention of earnings, the $W a b a s h$ rule tends to check only the unimaginative common stockholders' board.2s

Nevertheless, the Second Circuit should have stayed within the Wabash formula. Not only has the rule, on the books for over twenty years, served notice on draftsmen of preferred stock contracts, but doubtless has been reflected in market quotations on outstanding non-cumulative preferred. Overturning Wabash might provide a windfall for stockholders who bought at prices that took account of the rule. MIoreover, non-cumulative preferred was typically issued not to attract new capital of the investing public, but as a stopgap refinancing toobl of corporations in distress or as a bonus to existing stockholders. ${ }^{29}$ Since these circumstances would not seem to foster high hopes in non-cumulative preferred stockholders, adherence to the Wabasil rule probably accords with their investment expectations..$^{\text {ig }}$

26. Cf. Bassett v. U.S. Cast Iron Pipe \& Foundry Co., 74 N.J.Eq. 668, 70 Atl. 939 (1908), aff'd, 75 N.J.Eq. 539, 73 Atl. 514 (1909).

27. Wabash Railway v. Barclay, 280 U.S. 197, 204 (1930).

28. However, a judge looking at the end result of a series of retentions, may use hindsight to rule that the retentions were improper at the time they were made.

29. "[T] occasions. It has been issued chiefly at the time of the reorganization of failed corgorations as a kind of preference stock involving the least burden on the new company struggling to regain its solvency. It has been issued at the time of the recapitalization of solvent concerns, as a kind of common stock endowed with some slight advantage over ordinary common stock. And, finally it has been given to shareholders as a stocl: dividend, a present a 'little higher' than ordinary stock, yet a present not likely to embarrass the giver." 1 Dewing, Financial Policy of Conforitions 151 (4th Ed. 1946). "All those [non-cumulative stock issues] listed within the past ten ycars arose out of railroad re-organizations except United Stores Corporation which was a re-capitalization." Communication to the Yale LAW Jourival from Philip L. West, Vice-President, New York Stock Exchange, dated December 28, 1951 in Yale Law Library.

30. Courts and commentators alike have been quick to attempt telepathy in this field. Compare Wabash Railway v. Barclay, 280 U.S. 197, 203 (1930) ("[T]he common understanding of lawyers and businessmen. . . .) with Lattin, Is Nos:-Cumuslatice Preferred Stock In Fact Preferred?, 25 IL工. L. Rev. 148, 158 (1930) ("[T]he reaconable and more widely recognized meaning. ..."-contradicting Justice Holmes). Neither author cited source material. 
Because the ambiguity of the term "non-cumulative preferred" invites litigation, clarity in the stock contract should be the goal. In future stock issues, all corporations should set out clearly the non-cumulative preferred stockholder's dividend rights. Although the Securities and Exchange Commission probably would compel future issuers to disclose these rights in registration statement and prospectus, ${ }^{31}$ investors in security issues exempt from federal regulation ${ }^{32}$ must look to state blue-sky laws for protection. Disclosure-type laws ${ }^{33}$ might well require non-cumulative preferred rights to be clearly stated. Alternatively, regulations should presume every future issue of non-cumulative preferred to be cumulative if earned, unless the contract made another meaning clear. ${ }^{34}$ In this way, corporations would remain free to draft any clear preferred contract terms that investors would accept, while unambiguous disclosure would result. The market price would accurately reflect the non-cumulative stock's rights. And stockholders would no longer need to resort to courts to learn what rights they bought with their stock.

\section{GROUP LIBEL LAWS: ABORTIVE EFFORTS TO COMBAT HATE PROPAGANDA*}

MINORITY groups are frequently the targets of hostile language. Still vivid is the memory of the wave of methodical defamation on which the Nazis rode

31. "I think ... that we would require a clear disclosure of the substance of the Wabash holding." Communication to the Yale LAw Journal from Louis Loss, Associate General Counsel, Securities and Exchange Commission, dated December 5, 1951 in Yale Law Library. See Schedule A, 15 U.S.C. $\$ 77$ aa (1946).

Stock exchanges may also require some disclosure. "Our requirements covering listed securities include, among others, the following: Certificates of each class of stock must contain a statement of the rights and preferences of all classes of authorized capital stock as granted by the certificate of incorporation or by-laws, as the case may be. In some instances we have accepted summaries in lieu of verbatim transcripts." Communication, supra note 29.

32. Regulation A, drafted by the SEC pursuant to $\S 3(\mathrm{~b})$ of the Securities Act of 1933, 48 STAT. 74 (1933), 15 U.S.C. \$77a (1946), exempts inter alia issuing corporations' security distributions which do not exceed $\$ 300,000$ in any year.

The SEC may soon move to exert more thoroughgoing control over small issucs. See Crane, Changes Expected on Security Filing, N.Y. Times, October 14, 1951, p. 1, col. 6.

33. For discussion of this type of state regulation, see Atrins, Edwards, \& Moulton, The Regulation of the Securities Market 54-6 (1946); Wright, Corrclation of State Blue Sky Laws and the Federal Securities Acts, 26 CORNELL L.Q. 258 n.2 (1941).

34. In states where.existing administrative agencies are without sufficient power, this presumption would have to come from legislation. The existence of this presumption would speedily come to the attention of the corporate bar who would draft stock contracts with the presumption in mind.

*People v. Beauharnais, 408 I1l. 512, 97 N.E.2d 343 (1951), cert. granted, 342 U.S. 809 (1951). 
to power. ${ }^{1}$ In the United States, demagogues occasionally stimulate racial and religious prejudices to gain political appeal.2 But more serious are the activities of professional hatemongers. The "business" of these individuals and organizations is concentrated attack on minority peoples. ${ }^{3}$ Although less influential in recent years, ${ }^{4}$ their dogged attempts to incite inter-group hostility create continual possibilities of race riots and other violent outbursts.5

Under existing civil and criminal libel doctrines, defamers of sizable groups are immune if legally astute enough to avoid direct reference to an individual. ${ }^{\circ}$

1. See Riesman, Democracy and Defanation: Control of Group Libel, 42 CoL L. Rev. 727, 728-9 (1942); Riesman, Dentocracy and Defanation: Fair Gone and Fair Comnnent I, 42 CoL. L. Rev. 10S5, 10S8-1111 (1942).

2. For a discussion of Southern demagoguery, see Mryzdal, Ast Asrerscnsi Dinearara 455-62 (1944).

Prejudice against the Negro vas apparently stimulated and used to gain support for the Prohibition movement, and against the Wages and Hours Law. Id. at 456-7.

3. For a survey of the general activities, annual income, major contributors, and publication circulation of such notable hate propagandists as Gerald L. K. Smith, Joseph P. Kamp, Upton Close, Merwin K. Hart, and A. Alderson Zoll, see Fonsten, A Mreasure of FreEdoxi 36-79 (1950). See also id. at S1-8 for a survey of lesser figures. The 1949 incomes of the leading hate propagandists are reported as follows: Gerald L. K. Smith $(\$ 150,000)$; Merwin K. Hart $(\$ 140,000)$; Gerald Winrod $(\$ 100,000)$; Upton Close $(\$ 50,000)$; Joseph Kamp $(\$ 50,000)$; Allen Zoll $(\$ \$ 0,000)$; Wesley Swift $(\$ 40,000)$. Id. at 80 . For a list of hate propaganda groups, their periodicals, books, pamphlets, and leaflets, and pertinent facts about them, see id. at 222-39.

For an analysis of the types of propaganda media employed by anti-Semitic organizations in the United States during 1947 and 1948, see Wemitraud, How Securis THESE RIGHTS? 92-5 (1949), indicating that pamphlets and leaflets vere the most frequently employed media.

4. The defeat of fascism in World War II had a deterring effect on the activities and influence of the professional hate groups. See Fonsrer, op. cit. stpra note 3, at 81 , indicating that the number of hate groups in the United States grew from 60 in 1940 to 130 in 1946, and then dwindled to 66 in 1949.

5. For an analysis of race riots and other forms of violence, see MrynoAl, A:t AnIERTCAN DILEarara 558-69 (1944). Of all the violent outbursts of racial tension stimulated by hate groups during World War II, the Detroit riot of June 20, 1942, was probably the worst. See $i d$. at 568; Life, Aug. 17, 1942, p. 15-23.

See also Maslow, Group Libel Recostsidered, Congress Weclily, Jan 23, 1948, pp. 8-9; Perlman \& Ploscowe, False Defanatory Anti-racial and Anti-rcligious Profaganda and the Use of the Mails, 4 LAw. Gond Rev. 13-14 (Jan.-Feb. 1944).

6. If the libelled group is large (more than a dozen or so prople), no individual member has a civil remedy unless he shows that the libel refers directly to himself. E.g., Noral v. Hearst Publications, Inc, 40 Cal. App. 2d 348, 104 P.2d 860 (1940) (suit by one of 162 labor union officers failed because could not show libel referred to himself). The individual has a remedy only if the group is so small that the libal necessarily applies to each member, or if the libel applies to each member individually and not solely to the group as a collectivity. For extensive surveys of toth successful and unsuccessful actions by individual members of defamed groups, see Riesman, sspro note 1, at 756-64; Tanenhaus, Groutp Libcl, 35 Cors. L.Q. 261, 263-6 (1950); Wilner, The Civil Liability Aspects of Defantation Directed Against a Collcetivily, 90 U. of PA. L. REV. 414, 415-21 (1942). 
Hence specific statutes have been advocated to subject hate propagandists to effective legal sanctions. ${ }^{7}$ It is contended that consistent convictions under "group libel"s laws would drain the resources of hate organizations, thus discouraging future activity. 9 Psychic harm suffered by members of systematically defamed groups could be partially alleviated by such convictions, whereas absence of legal sanctions against hate propagandists might tend to create, in

Common law criminal liability presumably rests upon the tendency of the defamation to provoke breach of the peace, and could, therefore, in theory, be imposed in libel cases in which there is no civil liability. People v. Spielman, 318 IIl. 482,149 N.E. 466 (1925) (newspaper article charging the American Legion with venality and lawlessness held a criminal libel); People v. Gordon, 63 Cal. App. 627, 219 Pac. 486 (1923) (publisher of $\mathrm{Ku}$ Klux Klan magazine criminally liable for falsely alleging that Knights of Coumbus had taken vicious oath); 86 CENT. L.J. 334, 337 (1918). But close investigation of the few successful prosecutions reveals that in each there was a direct attack on some individual member of the group. E.g., People v. Edmondson, 168 Misc. 142, 144-55, 4 N.Y.S. 2d 257, 262-9 (Ct. Gen. Sess. 1938) ; People v. Spiclman, supra, where the court ruled that the libel need not be directed at an individual for criminal liability; but, in fact, individual Legionnaires were defamed.

Some courts have apparently abandoned breach of peace as a criterion for criminal group libel. See, e.g., People v. Edmondson, stipra, in which the court dismisscd an indictment for libelling all persons of the Jewish faith, ruling that the essence of criminal libel is the harm done to the individual in his community; Drozda v. State, 86 Tex. Crim. R. 614, 218 S.W. 765 (1920), in which the court reversed a conviction for libelling all Bohemians, ruling that the specific personal criminal intent necessary for conviction cannot be imparted to the publication when it does not clearly indicate the individuals meant to be attacked.

7. Libel actions, both civil and criminal, are of relatively little importance in this country, quantitatively. This is indicated by the few available statistical surveys, despite their narrow scope. See, e.g., Clark \& Shularan, A Study or Law Administration IN Connecticut 12-13, 28, 31, 44 (1937), indicating that in Connecticut, over a 14 year period, less than $1 \%$ of all litigations involved slander or libel.

The Fourte Decenntal Digest, covering the years from 1926-1936, lists 52 criminal libel proscutions; The FIFTH Decenratal Digest lists only 15 for the 1936-1946 period. The General Digest lists 1 for 1946, 0 for 1947, 1 for 1948, 1 for 1949, 2 for 1950, and 3 for 1951.

8. "'Group libel' is a rag-bag phrase used to include a wide range of critical comment that particular groups find objectionable. In broad terms, group libel laws may be said to be enactments whereby the publishers and disseminators of statements that tend to disparage racial and religious groups are rendered legally responsible for their actions." Tanenhaus, supra note 6 , at 262 .

9. The firmest advocates of group libel legislation admit that consistent convictions would be difficult to obtain. See, e.g., National Comsunnity Relations Advisory Councti Bulletin No. 11, Federal Group Libel Legislation (1949), supporting the Javits-Klein Bill, cited infra note 14: "Lax enforcement, however, is an evil by no means limited to group libel legislation. ... The apathy with which some state FEPC laws are administered is no reason for giving up the fight for FEPC. The only remedy for lax enforcement is vigorous enforcement, not abandonment." Id. at 3. But sec Riesman, supra note 1, at 755-6, rejecting criminal group libel legislation because the possibility of consistent enforcement is so remote. 
the victims, disrespect and distrust for the law. ${ }^{10}$ Group libel statutes could favorably influence the behavior of individuals by deterring those tempted to indulge in hate activities and reinforcing the reluctance of others to participate. ${ }^{11}$ And in the current cold war propaganda campaign, group libel legislation might help convince non-Americans that the United States sincerely wishes to reduce racial discrimination. ${ }^{12}$

Efforts to enact workable legislation, however, have met with little success. ${ }^{13}$ A number of federal group libel bills, based on the postal and commerce powers, were defeated in Congress between 1935 and 1949.14 Criminal statutes in eight states permit prosecution of various types of group libel. But lax enforcement and judicial restrictions have limited their effectiveness. Three show no successful prosecutions, ${ }^{15}$ two are so narrowly drawn as to merit little consider-

10. See Lusky, Minority Rights and the Public Interest, 52 YALE L.J. 1 (1942) for a general discussion of the importance of maintaining a policy which engenders in minority groups a respect for the law.

On lack of trust for the law on the part of Negroes, and its causes and effects, see MIYrdal, An Aaterican Dilezrara 525-6 (1944).

11. See in this connection Polier, Law', Conscince and Socicly, $6 \mathrm{LAw}$. Gumb Rev. 490 (1946).

12. On the international aspects of discrimination in the United States against the Negro, see Myrdal, An Americais Dilearasa 1015-8 (1944); Buch, Assericas: Unitr AND AsIa 29 (1942).

13. Debate has flourished on the advisability of such legislation. See, eg., Cousins, Editorial, Saturday Review of Literature, Feb. 1, 1947, p. 20, requesting an esploration of the problem of how to deal with hate propagandists through some form of "group libel" enactment. 200 or more letters were received in response, most of them opposing such proposed enactments. Id., March 15, 1947, pp. 23-4. See also N.Y. Times, MIarch 13,1947 , p. 25, col. 7.

14. For a survey and criticism of some of these proposals, see Baum, Good-and Bad-Libel Bills, Congress Weekly, Sept. 19, 1949, pp. 9-12, appraising the Barrett Bill, H.R. 3908, S1st Cong., 1st Sess. (1949), the Davenport Bill, H.R 3882, 81st Cong., 1st Sess. (1949), the Javits-Klein Bill, H.R 2269. 81st Cong., 1st Sess. (1949), and the Lynch Bill, H.R. 2328, 7Sth Cong., 2d Sess. (1943). See also Nam10:ins Co:s-

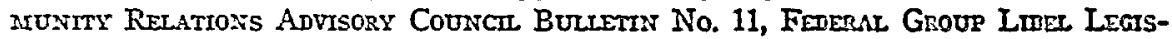
LATION (1949), discussing the Javits-Klein Bill, sıpra; Perlman \& Ploscone, sspro note 5, favoring the Iynch Bill, supra; Stewart, infra note 41, at 12-14, discussing the Buel:ley Bill, H.R. 2848, 80th Cong., 1st Sess. (1947), and a group libel proposal drafted by Professor Jerome Michael of Columbia Law School.

For an extensive survey of existing municipal group libel ordinances, see Tanenhaus, stipra note 6 , at 283-5.

15. MLass. Gen. Laws c.272, $\$ 98 \mathrm{C}$ (Supp. 1950); Ner. Coxrp. Laws $\$ 10110$ (Hillyer 1929); N. Miex. Stat. ANw. $\$ \$ 41-2725-7$ (19.41).

Of these the Massachusetts statute alone is directed at racial and religious hatred. See Note, 28 MLAss. L.Q. 104 (1943), discussing the statute (sponsored by the Ameriean Jewish Congress) and its background.

The protection of the New MIexico statute is limited to a "fraternal or religious order or society."

The Nevada statute defines criminal libel so broadly that it might be the basis for a group libel prosecution: "A libel is a malicious defamation ... tending to ... impeach 
ation as anti-hate legislation, ${ }^{16}$ and the broadest measure, the Indiana "antiracketeering" statute, is still untested. ${ }^{17}$ The New Jersey statute, ${ }^{18}$ enacted in 1937 to combat the growth of the German-American Bund, has been declared unconstitutionally vague with regard to speeches, and serious doubt has been cast on the constitutionality of its broad libel provisions. ${ }^{10}$

People v. Beauharnais ${ }^{20}$ is the first conviction under a group libel statute to be upheld by an appellate court. ${ }^{21}$ The case arose under the Illinois group libel law, ${ }^{22}$ enacted in 1917, and provided its first direct constitutional test. ${ }^{23}$

the ... reputation ... of a living person or persons, or conmutnity of persons, or association of persons. ..."

16. Conn. Rev. Stat. c.417, §8376 (1949); W.VA. Code Ann. $\$ 6109$ (1949).

The Connecticut statute applies only to advertisements. It is a criminal offense to "ridicule or hold up to contempt any person or class of persons, on account of the creed, religion, color, denomination, nationality or race of such person or class of persons. ..." in an advertisement.

The West Virginia statute is limited to pictures and theater performances which "injuriously reflect upon ... . any race or class of citizens, calculated to result in arousing the prejudice, ire or feelings of one race or class of citizens against any other race or class of citizens."

See also California Educations Code $\$ \$ 8271-2$ (1943), forbidding teachers and textbooks from reflecting upon citizens "because of their race, color, or crced," violation of which may involve dismissal.

17. IND. Stat. $\S 10-904-14$ (Burns 1933), enacted in 1947 to combat the Ku Klux Klan. See Tanenhaus, supra note 6, at 281-3, evaluating the Indiana statute. Sec also Maslow, Proposed Revision of Indiana Anti-Hate Bill (Commission on Law and Social Action Report, Mimeo.) (Jan. 16, 1947).

18. N.J. Stat. ANn. tit.2, c.157B, $\$ \S 1-8$ (1937).

19. State v. Klapprott, 127 N.J.L. 395, 22 A.2d 877 (Sup. Ct. 1941), 42 Cot. L. Rev. 857 (1942).

See also Winters v. New York, 333 U.S. 507, 517 (1948) (declaring invalid a statute prohibiting publication of "criminal news, police reports, or ... stories of decds of bloodshed, lust or crime..." as being vague and indefinite, and failing to give notice of what acts will be punished).

20. 408 I1l. 512, 97 N.E.2d 343 (1951), ccrt. granted, 342 U.S. 809 (1951).

21. The case was tried before a jury which found defendant guilty. He was fined the maximum sum of $\$ 200$. People v. Beauharnais, supra note 20 , at 515,97 N.E.2d at 345 .

22. Ilr. Rev. Stat. c.38, $\$ 471$ (1951) making it unlawful for "any person . . . to manufacture, sell, or offer for sale, advertise or publish, present or exhibit in any public place in this state any lithograph, moving picture, play, drama or sketch, which ... portrays depravity, criminality, unchastity, or lack of virtue of a class of citizcns, of any race, color, creed or religion ... or . . . exposes the citizens of any racc, color, creed or religion to contempt, derision, or obloquy or which is productive of breach of the peace or riots. Any person ... upon conviction thereof, shall be punished by a finc of not less than fifty dollars, nor more than two hundred dollars."

23. For a prior decision vaguely implying constitutional validity, see Bevins v. Prindable, 39 F. Supp. 70S, 712 (E.D.I11.), aff'd mem., 314 U.S. 573 (1941) (Jeliovah's Witnesses denied injunction against enforcement of $\$ 471)$. The District Court stid that it was not passing on the constitutionality of the statute; and that even if unconstitutional, an equity court might deny the injunction on the ground that there is no 
Beauharnais, president of the "White Circle League of America," prepared, and distributed on the streets of Chicago, leaflets which defamed all Negroes."4 There was no sign of violence. ${ }^{25}$ Nevertheless, he was convicted in the municipal court of Chicago. On appeal, he challenged the statute's constitutional validity. ${ }^{26}$ The Supreme Court of Illinois rejected the claim that the statute was too vague and held that Beauharnais' acts created a "clear and present danger" which justified abridging his right to free expression."

immediate threat of irreparable damage. The court said, however, that though the statute is vague and indefinite, it deals with a type of offense which defies definitiveness. See also Fox Film Corp. v. Collins, 236 Ill. App. 281 (1925) (upholding the validity of $\$ 2787$ of the Chicago Miunicipal Code, similar to $\$ 471$ ).

In 1941, $\$ 471$ was employed to some extent against Jehovah's Witnesses. See Bevins v. Prindable, supra at 713 , where the court notes that more than a score of cases involving violations by Jehovah's Witnesses were then pending.

The only prior appealed conviction under $\$ 471$ was reversed with no constitutional finding. Yeople v. Simcox, 379 Ill. 347, 40 N.E.2d 525 (1942) (reversing a conviction of a Jehovah's Witness, under $\$ 471$, for distributing anti-Catholic leaffets). Although the language of $\$+71$ does not seem to refer to leatlets, the court regarded the word "sketch" as including general printed material. The scope of the statute, originally intended to enable the state to censor motion pictures, Fox Film Corp. v. Collins, supro, has thus been greatly expanded.

24. On Jan. 6, 1950, the defendant called a meeting of the White Circle Lasgue to obtain volunteers who would, on the following day, distribute and obtain signatures on the leaflets. They were printed sheets of paper in the form of petitions to the city council and Mayor Kennelly of Chicago. They were headed in large black letters: "Preserve and Protect White Neighborhoods! From the Constant and Continuous Invasion, Harrassment and Encroachment by the Negroes." They went on to solicit the aid of one million white citizens of Chicago to oppose "Truman's Infamous Civil Rights Program," and attack pro-Negro organizations as attempting to mongrelize the white race. It was then pointed out that the "League" is the only instrument in America combatting Negro aggression; that white people must unite; that "if persuasion and the need to prevent the white race from becoming mongrelized by the Negroes will not unite us, then the aggressions . . . rapes, robberies, knives, guns, and marijuana of the Negro, surely will." People v. Beauharnais, stipra, note 20, at 514, 97 N.E.2d at 345.

25. The State conceded that there was no breach of the peace. Brief for Appellees, p.7, People v. Beauharnais, supra note 20.

It is not necessary for prosecution under $\$ 471$ that the language be "productive of breach of the peace or riots," that clause being written in the disjunctive. See note 22 stipra.

26. The court erroneously asserted, id. at 517,97 N.E.2d at 346 , that the Illinois statute was held constitutionally valid in Bevins $v$. Prindable, 39 F.Supp. 708 (E.D.III. 1941).

27. In its discussion of the First Amendment question, after restating the "clear and present danger" principle as originally formulated in Schencls v. United States, 249 U.S. 47,52 (1919), the court said: "A mere reading of the libelous jublieation in question here, refers to Negroes as a class possesssing various criminal tendencies, unchastity, and degrading sexual inclinations, all of which are 'fighting words' liable to cause violence and disorder between the races." People v. Bealharnais, sisfra note 20 , at 517,97 N.E.2d at 346 . Two discrete tests of the appropriateness of abridging freedom of speech are thereby confused. The first of these, the "fighting words" test, was formulated in Chaplinsky v. New Hampshire, 315 U.S. $56 S$ (1942). It covers 
In deciding the First Amendment question, the Illinois court said Beallharnais was not entitled to constitutional protection since "riots would cvcnttlally result between the members of the White Circle League of America and the Negro race."2s The focus of the "clear and present danger" test, however, has always been on the immediacy of the threat. ${ }^{20}$ At first the test was applied in cases where expression created danger of overthrow of, or serious injury to, the government. ${ }^{30}$ Subsequently, it was also applied to expression which threatened breach of the peace. ${ }^{31}$ Although the immediacy requirement was recently modified in Dennis v. United States, ${ }^{32}$ where the danger was overthrow

only utterances reflecting the bare emotion of the speaker or writer which, by their very utterance, inflict injury or tend to incite an immediate breach of the peace. It is felt that such expressions are no essential part of any exposition of ideas, and arc therefore without the scope of the First Amendment. Id. at 571-2. It is only when the utterance is within the scope of First Amendment protection that the sccond test, the "clear and present danger" test, is applicable. See Note, 47 CoL. L. Rev. 595,605 (1947).

28. (Italics supplied), People v. Beauharnais, supra note 20, at 517, 97 N.E.2d at 346.

29. See, e.g., the original statement of the test in Schenck v. United States, 249 U.S. 47, 52 (1919).

See also Thomas v. Collins, 323 U.S. 516 (1945) (state statute requiring registration of labor organizers held invalid as applied); Taylor v. Mississippi, 319 U.S. 583 (1943) (invalidating the part of a statute which forbade the teaching and advocacy of refusal to salute the flag during wartime, as constituting a danger too remote to satisfy the requirements of the test); Bridges v. California, 314 U.S. 252, 263 (1941) (reversing convictions for contempt of court): "What finally emerges from the clear and present danger' cases is a working principle that the substantive evil must be extremely serious and the degree of imminence extremely high before utterances can be punished."

For a detailed survey of the "clear and present danger" cases, see Appendix to Opinion of Mr. Justice Frankfurter, Dennis v. United States, 341 U.S. 494, 556-61 (1951); Antieau, The Rule of Clear and Present Danger: Scope of its Applicability, 48 MrCe. L. Rev. 811 (1950); Riesman, Civil Libertics in a Period of Transition, Syllabus and Selected Readings for Social Sciences 3 at the University of Chicago 290-9 (13th ed. 1947). See also MeikLejoun, Free SpEech and Its Relation to SELF-GovernMent 28-56 (1948) discussing and evaluating the test.

30. The test was first articulated and applied by Mr. Justice Holmes in Schenck v. United States, 249 U.S. 47, 52 (1919) (affirming conviction for conspiracy to violate the Esp.onage Act of 1917). Next, the test was applied in Frohwerk v. United States, 249 U. S. 204 (1919) (affirming conviction for conspiracy to obstruct recruiting in violation of the Espionage Act of 1917), and Debs v. United States, 249 U.S. 211 (1919) (affirming conviction for conspiracy to violate the Espionage Act of 1917).

31. Thornhill v. Alabama, 310 U.S. 88 (1940) (invalidating an Alabama statute forbidding loitering or picketing). See also, e.g., Cantwell v. Connecticut, 310 U.S. 296 (1940) (solicitation of funds by Jehovah's Witnesses who played records describing books which they were selling door-to-door and in the streets of New Haven held not to constitute a clear and present danger of breach of the peace).

The first curtailment of an expression threatening breach of the peace, under an application of the test, seems to be Milk Wagon Drivers Union of Chicago, Local 753 v. Meadowmoor Dairies, Inc., 312 U.S. 287 (1941) (affirming an order enjoining picketing because of threat of violence).

32. 341 U.S. 494 (1951). Here the Supreme Court affirmed a conviction of 11 Communist leaders under the Smith Act. 54 Stat. 670 (1940), as amended 62. StAT. 
of the government, the test has never been relaxed in the case of threatened breach of the peace. ${ }^{33}$ Since in such cases the threat is merely to local public order, legislative limitations on expression should be scrutinized more carefully. When there is no immediacy such restrictions would still seem to be unconstitutional.

Possible infringement of First Amendment rights is not the only undesirable feature of group libel laws. Chances of effectiye enforcement are lesscned by

S0S (1948), 18 U.S.C. $\$ 2385$ (Sunp. 1951). The majority of the Court indirectly repudiated the "immediacy" requirement by adopting $i d$. at 510 , Judge Learned Hand's reformulation of the "clear and present danger" test: "In each case [courts] must ask whether the gravity of the 'evil', discounted by its improbability, justifies such invasion of free speech as is necessary to avoid the danger." United States v. Dennis, 183 F.2d 201, 212 (2d Cir. 1950). See Mrr. Justice Blacl's dissent, Dennis v. United States, supra at 579-81, in which he accuses the majority of the Court of "jettisoning" the "clear and present danger" rule, and Mr. Justice Douglas" dissent, id. at 5\$1-91, in which he reaffirms the importance of strict adherence to the "immediacy" requirement.

For a detailed analysis of the "clear and present danger" test, and its applieation in the Dennis case, see Richardson, Frecdom of Expression ant the Funclion of Courts, 65 HARv. L. REv. 1 (1951).

See also Nathanson, The Commmist Trial and the Clcar-and-Present-Danger Test, 63 Harv. L. Rev. 1167 (1950); Note. The Cleur and/ar Present Langar Lerdrme: A New Equation, 5 Rutgers L. Rev. 413 (1950).

33. See, e.g., Cantwell v. Connecticut, 310 U.S. 296, 307-11 (1940), in which the Court set aside a conviction for inciting a breach of the peace on the ground that the "immediacy" requirement had not been met. The Court maintained that in practically all of the decisions curtailing expressions threatening bresch of the peace, "the provoentive language ... consisted of profane, indecent, or abusive remarls directed to the person of the hearer." Id. at 309. The decision was based on a finding that there was "no assault or threatening of bodily harm, no truculent bearing, no intentional discourtesy, no personal abuse." Id. at 310.

Also, compare Terminiello v. Chicago, 337 U.S. 1 (1949), avilh Feiner v. New Yorls, 340 U.S. 315 (1951). In the former case the breach of peace ordinance under which defendant was convicted was ruled invalid as construed by the trial court on the ground that it undermined the "immediacy" requirement by curtailing speech which simply "stirs the public to anger, invites dispute, brings about a condition of unrest, or creates a disturbance. ..."

In the latter case the defendant, speaking at an open air meeting, was convieted for disorderly conduct. The evidence was held sufficient to sustain a finding that Feiner was deliberately trying to arouse Negroes against whites, and that the police did not step in until necessary to prevent a riot. Feiner was not arrested until, aiter scveral requests, he refused to descend from the speaker's platform. Thus, in both ases immediacy was the essential criterion, although curtailment of expression was upheld in the second and not in the first.

34. That the "immediacy" requirement might be relaxed only when the danger is of a greater order of magnitude was implicit in Judge Find's reformulation of the "clear and present danger" test. See note 32 supra. This was pointed out by Richardson, supra note 32, at 17-18: "It seems . . accurate . . . to regard the factors of probability and gravity as varying inversely with each other to produce a quantum upon which the ultimate question of constitutionality depends: the more serious the cril if it should occur, the less strong need be the showing of its probability, and vice versa. ..." 
the likelihood of nullification either on the prosecution or jury level..$^{35} \mathrm{Ac}$ quittal, which might be taken as official approbation, would enhance the defendant's prestige. Conviction might make the defendant a martyr who could accuse the prosecution of violating civil liberties. Moreover, the necessarily vague language of a group libel statute makes it a legal blunderbuss, likely to hit wicle of the mark. ${ }^{36}$ To avoid the danger that expression not designed to stimulate prejudices will be subject to prosecution, most group libel laws have been hedged with purported safeguards. Typical is the provision that proof of truth constitutes a valid defense..$^{37}$ But giving defendants the chance to argute the "truth" of their hate canards would make the trials sounding-boards for their propaganda. ${ }^{38}$ Such "prosecutions" might be warmly welcomed by professionals. ${ }^{39}$

35. Either political fear or personal bias on the part of state attorneys could limit the number of prosecutions. Furthermore, members of the minority group in question would often be poorly represented on venire lists. But even if equally represented they might be readily recognized and quickly challenged. On the other hand, latent antiSemites and anti-Negroes would not be faced with these obstacles.

For a discussion of the problems of nullification, see Tanenhaus, stlpra note 6 , at 300 , in which he concludes: "The average jury would contain one person with a pronounced anti-Semitic outlook, and several more who were somewhat bigoted."

See also Analysis of Gillette Bill for Propaganda Exposure, 87 Conc. Rac. Arr. A1038 (1941).

36. See, e.g., Chafee, Governanent and Mass Communications 125.6 (1947) commenting upon vagueness as an inherent characteristic of group libel legislation.

37. E.g., Mass. Gen. Laws, c.272, §98c (Supp. 1950). This statute admits truth without qualification as an absolute defense. The defendant may also maintain the firmly established chief libel defenses of privilege, or absence of malice.

38. On the use of the "sounding-board" technique by the Nazi Party in its rise to power, and by Representative Sweeney of Ohio as Father Coughlin's spokcsman, sce Chafee, Governiment and Mass Communications 122 (1947).

For accounts of demonstrations staged in 'courtrooms by the Nazi, see N.Y. Times, June 10,1932, p. 6, col. 3, describing the insolence with which Hitler answered the court in a libel case against him, and the cheers of his admirers. See also N.Y. Timcs, Apr. 28, 1931, p. 54, col. 4.

For examples of the sort of vicious propaganda disseminated in the courtroom under the guise of proof of truth, see Brief for Appellants, p. 16, People v. Beauharnais, stupra note 20: "If one may comment upon this (the tendency of races to stick together) and show the possible evils of this cohesion, there could possibly develop in this country a revolution such as occurred in Haiti where the negroes overthrew the whites and became supreme."

39. That William Dudley Pelley welcomed his forthcoming trial is cvidenced by his statement in contemplation thereof: "What is being offered me on a silver platter by the Administration, it would seem, is the opportunity of my whole carecr to offer in tangible and positive shape what I know ... at last I would seem to have a forum where I can produce under Federal subpoena, data running into the truckload that ought to set off more internal blitzes than Adolf's Luftwaffe." Newsletter, May 18, 1942, p.2. See Sr. George \& Dennis, A Trial. on Trial: The Great Sedition Trial of 1944 (1946), for a discussion by the defense attorneys of the mass trial of 30 hate propagandist which, after $71 / 2$ months, ended in a mistrial caused by the death of the trial judge. 
Recognizing these failings, some advocates of affirmative legislation have proposed compromise methods for checking hate propaganda. One suggestion is a "compulsory reply" statute requiring the publisher of a libellous statement to print a rebuttal written by selected members of the libelled group. ${ }^{40}$ The most publicized of these proposals involves forming an "Advisory Committee" composed of one representative from each minority group." The Committee would decide whether to reply, and would appoint authors. The basis for its decisions would be the extent to which the libel is likely to mislead and the desirability of replying. The proposal aims to mitigate the effect of the defamatory statements while avoiding the shortcomings of criminal process under conventional group libel laws.

This approach, however, seems administratively unfeasible, and could do more harm than good. The "Advisory Committee" would have to reconcile the divergent views of various minority groups or impose its will despite them. Without substantial agreement either no reply would be ordered, or the reply would evoke the hostility of dissenters. Furthermore, delay, caused by intergroup disagreements, would lessen the reply's timeliness and tend to revive and reinforce the effect of forgotten libels. Even if not delayed, it would be effective only if better propaganda than the libel. The requirement that the reply be non-defamatory gives the libel a considerable edge. Finally, unsophisticated readers might assume that there must be some truth in the offensive statement, since the government wants to see it debated. Enveloping the libel with an otherwise unobtainable aura of importance might well be the net result of this expensive and time-consuming procedure.

A second alternative is a statute authorizing a civil suit for an injunction against continued group libel.42 The Columbia Lan Revicw drait is the one

40. This proposal is patterned after many foreign "reply" statutes, currently in effect, which apply only to individual and not group libel. See Rothenberg, Thic Right of Reply to Libels in the Press, 23 J. Cossp. LEG. \& INT'L L. 38 (1941), for a diseussion of the "reply" statutes which apparently are in effect in all of the major countries of the world with the exception of Great Britain and the United States.

See also C五AFEE, supra note 38 , at 145-86, discussing similar forcign "reply" measures. Chafee recommends that group libel not be included within the scope of the "reply" device. Id. at 185-6.

For a discussion of the German (Berichtigung) and the French (droit de refponse) laws, and their inadequacies, see Riesman, supra note 1, at 1109-17.

41. This proposal, in the form of a detailed outline, was submitted to the President's Committee on Civil Rights on June 5, 1947. It is a 32 page memorandum entitled, "Group Defamation and Civil Rights," prepared by Mrilton D. Stewrrt, Direetor of Research of the Committee. It was inspired by Professor Harold D. Lasswell's "Instant Reply Plan," which would require that all printed hate propaganda contain a reply under the same cover, and with equal legibility and prominence. Lasswels, Democracy Through Public Opinion 106-16 (1914).

42. IND. Stat. $\$ 10-907$ (Burns 1933) is the only legislation in this country offering the remedy of injunction. Like the remaining sections of the Indiana "anti-raclieteering" law, it is as yet untested. See note 17 supra. Under this section the injunction action must be brought either by a prosecuting attorney, or the Attorney General of the State. 
most worthy of consideration..$^{43}$ It would permit courts to enjoin not only repetition of the libel, but also its "substantial equivalent." Courts could also order the posting of a bond conditioned upon no further violation. Three provisions are designed to guard against strike suits : plaintiffs can obtain no damages; defendant may demand that plaintiff post a $\$ 300$ bond to guarantee the costs of an unsuccessful action; plaintiff is forbidden to discontinue the action voluntarily.

Although more manageable than the "reply" technique, this proposal has serious constitutional shortcomings. The doctrine prohibiting "prior restraints" on publication raises a considerable hurdle. ${ }^{44}$ While dissemination of familiar hate-instilling tracts, known beyond question to be false, might constitutionally be enjoined, courts' power to ban future publication of "stibstantially cquivalent" material is extremely doubtful. ${ }^{45}$

Aside from the question of constitutionality, the statute fails in other respects. To safeguard against suppression of legitimate publication, truth is made a defense. Once more it is this safeguard which weakens the statute and introduces dangers. The historical reluctance of equity courts to accept jurisdiction in cases involving the protection of "mere personality" 10 could readily lead them to a broad construction of the "truth" defense, so that partial "truth" would suffice. Few injunctions would then issue. Here, as in the criminal court, the "truth" issue involves the "sounding-board" danger. Here too, if

See also Manitoba Rev. Stat., c.119, \$14 (1940), (Canada), authorizing any member of the libelled group to seek an injunction.

43. Note, Statutory Prohibition of Group Defamation, 47 CoL. L. REv. 595, 609-12 (1947). This draft also contains a severable, narrowly drawn, criminal section to meet with the problem of breach of the peace.

44. Near v. Minnesota, 283 U.S. 697 (1930), is the case most nearly in point. The statute invalidated in that case permitted an injunction against all publication until stch time as the publisher persuaded the issuing judge that he would print nothing inproper. The Columbia Law Revieze draft merely prohibits repetition of the offensive matter.

45. See Tanenhaus, supra note 6, at 292-3, where it is suggested that such notoriously false publications as the "Knights of Columbus Oaths" and "The Protocols of the Learned Elders of Zion" might be enjoined without danger of First Amendment pitfalls. That the "Knights of Columbus Oath" has conclusively been held to constitute a criminal libel, see the four cases in point: Alumbaugh v. State, 39 Ga. App. 559, 147 S.E. 714 (1929); People v. Gordon, 63 Cal. App. 627, 219 Pac. 486 (1923); Crane v. State, 14 Okla. Crim. 30, 166 Pac. 1110 (1917) ; People v. Turner, 28 Cal. $\Lambda$ pp. 766, 154 Pac. 34 (1915). The unquestioned criminality of this publication is, for all practical purposes, as effective a "prior restraint" as would be preventive action by a court of equity. Tho penalty for committing criminal libel can hardly be said to be less deterrent than the penalty for violating an equity decree. So refusal to enjoin such an unquestioncd falsehood because of the rule against "prior restraints" would, at best, be unrealistic.

However, the same cannot be said of "substantially equivalent" material. In stich cases the criminality is not unquestioned until adjudicated, and an equity court might very well deny an injunction as a "prior restraint."

46. See, e.g., 38 Cor. L. REv. 1291 (1938) on the refusal of cquity courts to grant injunctive relief against defamation. See also Pound, Equitable Relicf Against Dcfamation and Injuries to Personality, 29 HARv. L. Rev. 640-51 (1916). 